PNL-9008

UC-600

\title{
Information on Hoover's Desert Parsley for Base Realignment
}

\author{
J. L. Downs \\ L. E. Eberhardt ${ }^{(a)}$ \\ V. W. Meadow ${ }^{(b)}$
}

December 1993

Prepared for the U.S. Department of the Army under a Related Services Agreement with the U.S. Department of Energy Contract DE-AC06-76RLO 1830

Pacific Northwest Laboratory Richland, Washington 99352

(a) Deceased.

(b) Department of Botany, Metropolitan State College, Denver, Colorado. 


\section{Summary}

Hoover's desert parsley, Lomatium tuberosum Hoover, is listed as a threatened species by the state of Washington (Washington Natural Heritage Program 1990) and is a candidate for federal consideration in the 1985 Federal Register, Notice of Review. A memorandum (8 August 1989) from the Deputy Assistant Secretary of the Army (Installations and Housing) stated that "candidate species and those proposed for listing will be treated as listed species when managing the natural resources or supporting military mission requirements." As a result of this management strategy, the U.S. Department of the Army at Ft. Lewis requested that Pacific Northwest Laboratory (PNL) perform a review of pertinent literature, survey the current populations of this plant, on the Yakima Training Center (YTC) during the spring months of 1992, identify likely habitat for the plant, and perform a search/survey for other populations on the YTC.

Results of this survey indicatef that Hoover's desert-parsley was more numerous on the YTC than previously believed. Relatively large numbers of plants were found in habitat adjacent to praviously known populations on the eastern edge of the YTC. Populations of this species appear to be limited to the very steep and unstable, basalt talus slopes on the eastern side of the YTC, adjacent to the Columbia River. Plants were located in areas at elevations between 200 and $700 \mathrm{~m}$. Most populations occurred on north- and northeastfacing slopes and along the ridgatops of south-facing slopes where $L$. tuberosum occurred on the northern slope of the ridge.

PNL staff did not locate Hoover's desert-parsley on the steep basalt talus slopes occurring on the-western edge of the YTC. The area in Selah Creek canyon was extensively searched, and we did not locate any populations there, although it had been found previously (in Selah Canyon in 1944). However, surveys by YTC biologists in the canyon during spring 1993 located populations of L. tuberosum at UTM coordinates $X 696800, Y 5175300$. The plant also may occur west of the YTC near the mouth of Selah Canyon. 


\section{Contents}

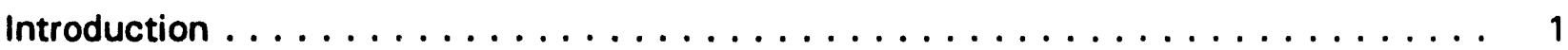

Life History and Distribution of Hoover's Desert Parsley $\ldots \ldots \ldots \ldots \ldots \ldots$

Field Survey Methods $\ldots \ldots \ldots \ldots \ldots \ldots \ldots \ldots$

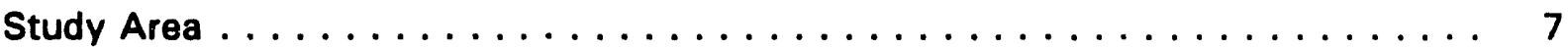

Survey of Known Populations $\ldots \ldots \ldots \ldots \ldots \ldots \ldots \ldots$

Search of Areas Near Known Populations $\ldots \ldots \ldots \ldots \ldots$

Identification and Survey of Other Likely Habitat $\ldots \ldots \ldots \ldots \ldots$

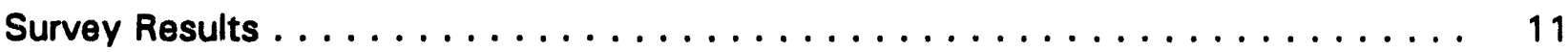

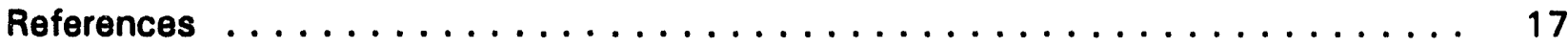




\section{Figures}

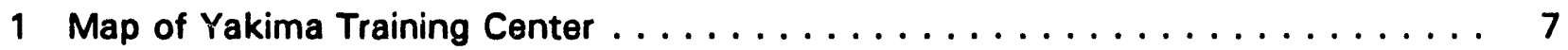

2 Areas on the Yakima Training Center Identified as Possible Habitat for Lomatium tuberosum $\ldots \ldots \ldots \ldots \ldots \ldots$

3 Areas on the Yakima Training Center Surveyed on Foot and Habitat Areas Where Lomatium tuberosum was Found . . . . . . . . . 13

\section{Tables}

1 Location Descriptions of Collected Specimens of Lomatium tuberosum Near the Yakima Training Center . . . . . . . . . . . . 5

2 Phenology Observations of Lomatium tuberosum on the Yakima Training Center in 1992 


\section{Introduction}

Hoover's desert parsley, Lomatium tuberosum Hoover, is listed as a threatened species by the state of Washington (Washington Natural Heritage Program 1990) and is a candidate for federal consideration in the 1985 Federal Register, Notice of Review. A memorandum (8 August 1989) from the Deputy Assistant Secretary of the Army (Installations and Housing) stated that "candidate species and those proposed for listing will be treated as listed species when managing the natural resources or supporting military mission requirements." As a result of this management strategy, the U.S. Department of the Army at Ft. Lewis requested that Pacific Northwest Laboratory (PNL) perform a review of pertinent literature, survey the current populations of this plant on the Yakima Training Center (YTC) during the spring months of 1992, identify likely habitat for the plant, and perform a search/survey for other populations on the YTC.

Several populations of Hoover's desert parsley were known to be located on the YTC: Township 15N, Range 23E, Section 33, NW $1 / 4$ of SW $1 / 4$ at $244 \mathrm{~m}$ in the Saddle Mountains at Sentinel Gap, and on Umtanum Ridge Township 13N, Range 23E, Section 4, SW $1 / 4$ of NE $1 / 4$. However, no methodical survey for the species on the YTC had been undertaken. The results of this survey from February 1992 to May 1992 include an inventory of existing populations on the YTC, maps of the locations of habitats for populations, information on the life history of the plant, and an evaluation of the impact of livestock grazing on Hoover's desert parsley.

A summary of the findings of these efforts is provided in this report. The data collected provide information on the status of Hoover's desert parsley on the YTC and aid in planning for protection of this threatened plant. 


\section{Life History and Distribution of Hoover's Desert Parsley}

Lomatium tuberosum Hoover is a talus endemic in Benton, Grant, Kittitas, and Yakima counties in south-central Washington. This distinctive species is characterized by an acaulescent habit (i.e., no stem protruding above the surface), pale yellow or pale purple flowers, yellow anthers, and small finely divided leaves grayish-green in color (Mastrogiuseppe et al. 1985). Plants of this species were previously collected in unstable talus slopes of small cobble-size basaltic rocks (Mastrogiuseppe and Gill 1983) at elevations from 140 to $475 \mathrm{~m}$ (Mastrogiuseppe et al. 1985). Previous collections of $L$. tuberosum were found on steep (45-60\%) north- or northeast-facing slopes between more densely vegetated bands with few actual associates: Delphinium nuttallianum Pritzel, Galium aparine L., Bromus tectorum L., Allium acuminatum Hook, Eriogonum niveum Douglas. and Poa sandbergii (Mastrogiuseppe et al. 1985).

The restricted distribution of the species and relative inaccessibility of habitat, as well as confusion with L. columbianum (Mastrogiuseppe et al. 1985, Constance, Chuang and Bell 1976), has limited critical examination of the species. First described in 1944 by R. F. Hoover from specimens collected at Fort Simcoe and White Swan, and later along Selah Creek, the species was thought to be limited to those areas. In 1980 and 1981, L. tuberosum was collected from northeast-facing talus slopes on Umtanum Ridge and in the Saddle Mountains. The first collection of $L$. tuberosum from outside the area defined by Hoover actually occurred 20 years before the species was described. St John collected the plant at the eastern end of Umtanum Ridge in 1922, but misidentified the specimen as L. columbianum. More recently, L. tuberosum has been collected in the Selah Creek vicinity: at the extreme western end of Umtanum Ridge at Selah Butte and on Baldy Mountain on Yakima Ridge near Yakima (Mastrogiuseppe et al. 1985) (Table 1).

The phenology of the species is not well known, but flowering occurs in early March to mid-April and fruiting in mid-April to early May. Observations of phenology are complicated because the species is subject to small mammal herbivory and insect predation. In the eastern range, many inflorescences, flowers, and leaf blades are nipped off before fruiting or even before anthesis, causing most plants in the eastern range to reproduce vegetatively. Insect larvae infestation of the fruits is frequent and often causes fruits to be atypical.

Lomatium tuberosum plants are widely scattered, and populations are not numerous. Apparently, suitable habitat exists on basaltic ridges in central Washington (e.g.. Rattlesnake Ridge, Frenchman Hills, Toppenish Ridge) other than those on the YTC (e.g., Yakima Ridge, Umtanum Ridge, and Saddle Mountains) and possibly in other areas. The nature of its habitat is favorable for the species continuance because threats to talus 
slopes are less than to other habitats, and according to Mastrogiuseppe et al. (1985), the plants do not appear to be heavily impacted by hoofed herbivores. Monitoring known populations and searching for other populations in like habitats will help assess the status of the species.

Cytotaxonomic work by Mastrogiuseppe et al. (1985) reveals that $L$. tuberosum is morphologically similar to L. columbianum, L. cuspidatum, and L. minus. All four of these species occur in rocky habitats and have woody, thickened tuberous roots, finely divided glaucous leaves, and purple flowers. L. columbianum, which is most likely to grow in the same region in similar habitats (and is often confused with L. tuberosum), is usually larger than the other three species. Lomatium cuspidatum is found in the Wenatchee region, and L. minus is found in central-southeastern Oregon. 
Table 1. Location Descriptions of Collected Specimens of Lomatium tuberosum Near the Yakima Training Center ${ }^{(a)}$

Description

Umtanum Ridge exactly 1 mile west of Midway Power Substation below Priest Rapids Dam. In very loose talus with few actual associates. Above trail through talus to cave house, $650 \mathrm{ft}$.

Umtanum Ridge, 0.5 miles west of Priest Rapids Dam about $1200 \mathrm{ft}$ in bunchgrass community; Grande Ronde Basalt, lithosols on loamy canyon slopes.

Kittitas County, Saddle Mountains at Sentinel Gap opposite Beverly trestle in talus slope interfingered with more stable areas; Northeast-facing slope at about $800 \mathrm{ft}$ with Delphinium nuttallianum, Lithophragma parviflora.

Yakima County, Umtanum Ridge just above Priest Rapids Dam at intersection of tributary wash (Astragalus columbianus site) with first major wash north of dam. Northeast-facing slope at about $1200 \mathrm{ft}$. in very loose talus with Allium acuminatum.
Location

Township 13N, Range 24E, Section 15 , NE $1 / 4$ of NW $1 / 4$

Township 13N, Range 23E, Section 3

Township 15N, Range 23E Section 33, NW $1 / 4$ of SW $1 / 4$

Township 13N, Range 23E, Section 4, SW $1 / 4$ of NE $1 / 4$

(a) Recorded from herbarium sheets from the Owenbey Herbarium at Washington State University, Pullman, Washington. 


\section{Field Survey Methods}

The approach to surveying for Hoover's desert parsley was threefold: 1) periodic visits were made to known populations of the species to provide information on phenology and number of plants in the population, 2) extensive searches were made of the area around these populations to look for newly established populations near a known seed source, and 3) land areas on the YTC were surveyed where similar habitat conditions exist.

\section{Study Area}

The 1,058-km ${ }^{2}$ YTC is located in south-central Washington in Yakima and Kittitas counties about $11 \mathrm{~km}$ north of Yakima. The YTC is bordered by the Columbia River on the east, Interstate Highway $1-82$ on the west, Manashtash Ridge on the north, and Yakima Ridge on the south (Figure 1). Umtanum Ridge, which bisects the YTC east to west, reaches elevations of $1,249 \mathrm{~m}$. The lowest elevation on the YTC is $183 \mathrm{~m}$. The climate of the area is characterized by hot, dry summers and cold, dry winters. Annual precipitation is approximately $20 \mathrm{~cm}$ per year. Temperatures range from $-40^{\circ} \mathrm{C}$ in January to $40^{\circ} \mathrm{C}$ in July.

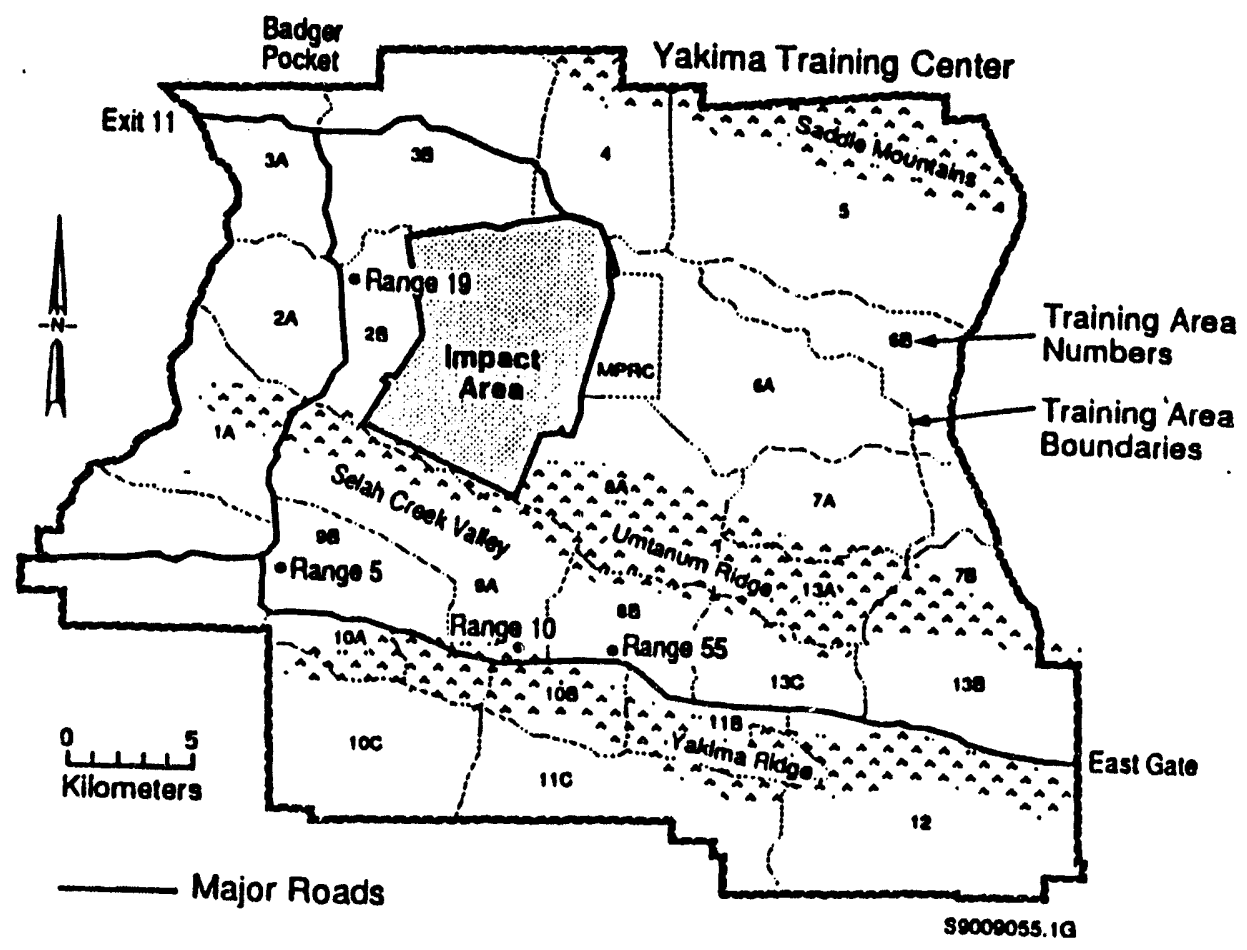

Figure 1. Map of the Yakima Training Center 


\section{Survey of Known Populations}

Known locations of populations of $L$. tuberosum on the YTC were visited periodically from February 5, 1992, until May 31, 1992, to gather information on phenology and vigor.

\section{Search of Areas Near Known Populations}

Because existing populations provide a lirely seed source, the areas surrounding existing populations were thoroughly surveyed on foot for the presence of desert parsley. These surveys included reconnaissance of similar habitat at elevations both below and above the existing populations and any likely habitat at the same elevation band within the vicinity. At the northeastern end of the YTC, surveys adjacent to known popularions of Hoover's desert parsley were conducted on a strip of northeast facing slope approximately $5000 \mathrm{~m}$ in length varying from 100 to $5.00 \mathrm{~m}$ in width. At the eastern boundary of the YTC adjacent to populations of desert parsley near Priest Rapids Dam, the area surveyed was approximately $4000 \mathrm{~m}$ in length, varying from 100 to $1000 \mathrm{~m}$ in width depending on the terrain.

\section{Identification and Survey of Other Likely Habitat}

Other areas consisting of steep, northeast-facing talus slopes on the YTC were also surveyed. Using the Geographical Resource and Analysis System (GRASS), areas meeting the habitat specifications for elevation, aspect, and slope weri identified on computer-generated maps. The habitat specifications that we used were as follows:

- elevations between 150 and $500 \mathrm{~m}$

- northwest to north- to northeast-facing aspects

- slopes greater than $16^{\circ}$.

Figure 2 shows these areas on the YTC where all three habitat specifications were met. Areas identified by slope, aspect, and elevation as likely habitat comprise a land area of $982.8 \mathrm{ha}\left(3.8 \mathrm{mi}^{2}\right)$ and include those areas on the east side of the YTC where populations of Hoover's desert parsley were known to occur. These areas were surveyed as extensively as possible during the spring growth season for desert parsley. Areas outside known locations of desert parsley populations were surveyed from vehicles where roadways were adjacent and by using spotting scopes and binoculars where roadways were not adjacent. If these areas were determined to be basalt talus slopes, they were surveyed on foot to search the ground for desert parsley.

Ground surveys on foot were conducted by walking through areas and up the slopes to any basalt cobble outcrops. Cobble areas associated with stabilized fingers or islands 


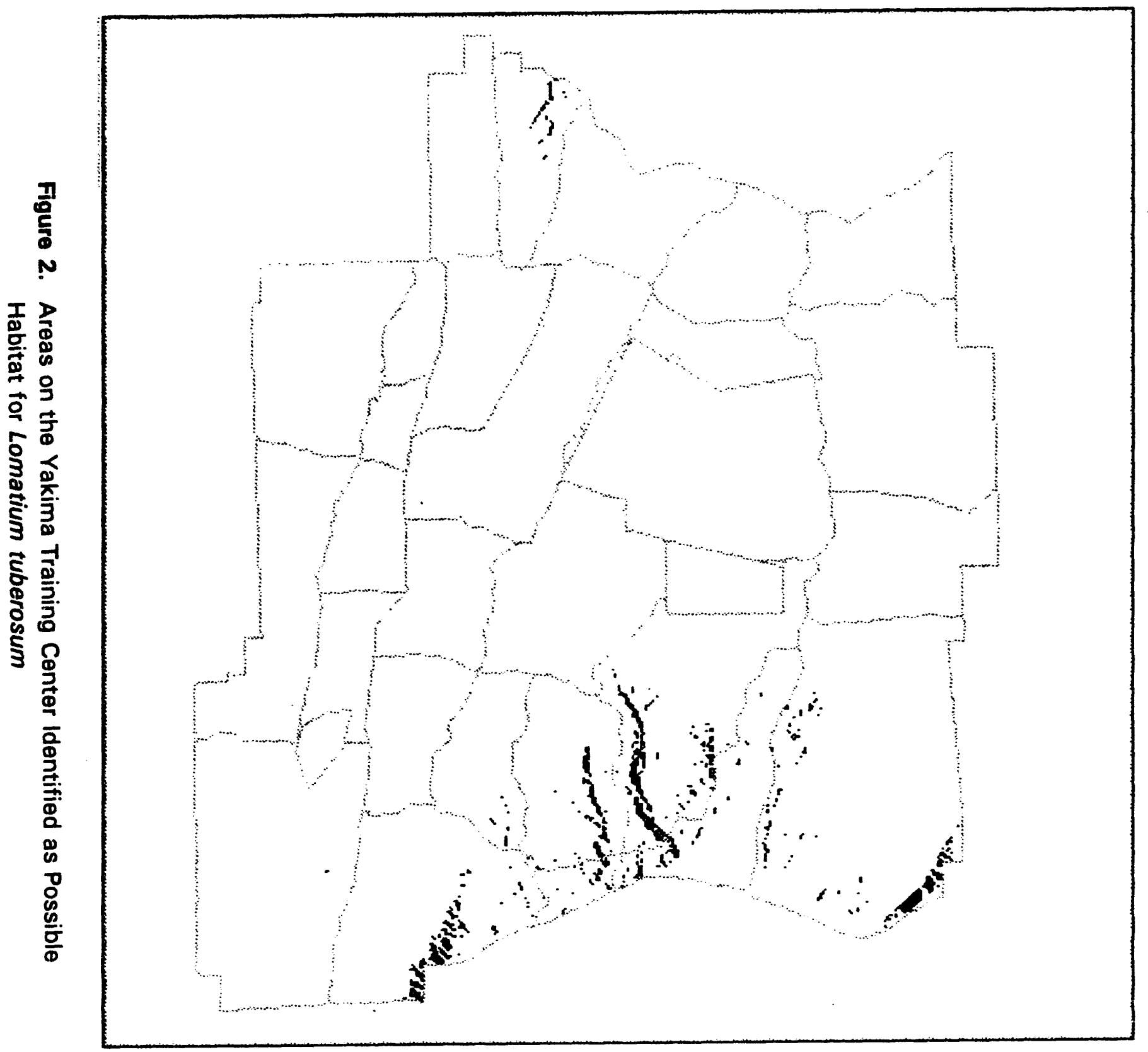


were identified and searched. If an entire slope was basalt talus, several transects were walked across the slope: 1) at the base of the basalt cobble, 2) midway between the base and upper limit of the basalt cobble, and 3) along the upper extent of the bacalt cobble, where possible. Some areas were too steep to climb.

If areas were visually determined to consist of stable, soil-covered slopes, they were not considered suitable habitat for Hoover's desert parsley populations and were not surveyed further. 


\section{Survey Results}

Surveys for L. tuberosum on the YTC were successful in locating comparatively large populations of this species (hundreds of individuals counted while traversing several hundred meters upslope). Most of the populations located are on adjacent slopes and in canyons adjacent to previously known populations on the eastern edge of the YTC. These 1992 surveys disclosed populations of this plant outside our initial habitat limitations of north-facing slopes and outside the elevations of 150 to $475 \mathrm{~m}$. Because in many areas individuals were too numerous to count, the survey results are presented in terms of habitat areas where $L$. tuberosum was found to occur (Figure 3 ), rather than specific locations of each grouping of plants. In many cases, groups of plants were separated by less than $20 \mathrm{~m}$. All the desert parsley populations located were on the eastern edge of the YTC and associated with steep basalt cobble slopes.

At the eastern side of the YTC above Priest Rapids Dam (Figure 3), Hoover's desert parsley was found on steep south-facing basalt-talus slopes near the ridge lines. These plants were found outside the known extent of desert parsley habitat, which is thought to be restricted to north-facing slopes. Plants were also found at and above $700 \mathrm{~m}$ in the habitat area above Priest Rapids Dam at the southern portion of the eastern side of the YTC. These elevations are higher than elevations of previously documented populations of desert parsley. Plants that were found at higher elevations and in the side canyons were quite vigorous, and populations and individuals were too numerous to count. For example, in the first canyon to the west inside the southeastern YTC boundary gate, located about $1.5 \mathrm{~km}$ north of Priest Rapids Dam, several thousand plants were counted within a $1-\mathrm{km}$ transect winding up through the canyon and along the ridge line.

Using the areas from the 982 ha of habitat originally identified by mapping slope, aspect, elevation, and observations of other suitable habitat not identified by the Geographic Information System (GIS), approximately 917 ha were determined to contain suitable habitat and were surveyed on foot. Figure 3 depicts only those areas surveyed on foot, and of those areas surveyed on foot, indicates the habitat areas where desert parsley was found. Figure 3 does not indicate all areas surveyed from vehicles and determined to be unsuitable habitat for Hoover's desert parsley.

The foot surveys included the Selah Creek Canyon area. Although apparently suitable habitat occurs in the Selah Creek Canyon area, we did not locate populations of Hoover's desert parsley there. Other surveys by YTC personnel located a population in a side canyon off Selah Canyon. This desert parsley species is apparently only found on basalt slopes where talus is still actively moving. Many of the slopes in the Selah Creek Canyon area on the west side of the YTC appear much more stable than slopes on the eastern side of YTC near the Columbia River,-and the cobble size of the basalt may be too large without enough finer material to support the species. 
Plants were most often found in association with the species previously mentioned (Mastrogiuseppe et al. 1985). At lower elevations (below $300 \mathrm{~m}$ ) L. tuberosum plants were malloften found beneath the canopy of sumac (Rhus glabra L.). The populations were often associated with small islands of stabilization on the steep basalt slopes. These islands may have small shrubs - either sumac or sagebrush - and bunchgrass growing in small accumulations of finer soils and gravels on the talus slope with some mosses and lichens. Hoover's desert parsley was most often found within $2 \mathrm{~m}$ of these more stable 'islands'; however, populations were also found in basalt cobbles at greater distances from the stabilized areas.

Evidence of small mammal herbivory on plant shoots and inflorescences was prevalent throughout the populations surveyed during February, March, and early April. Plants in known populations at lower elevations above Priest Rapids Dam were found in flower in mid-February (Table 2). Late winter and early spring weather was particularly mild in 1992 and contributed to early growth and flowering by a number of plant species in the area. Plants found at upper elevations appeared to flower and set seed a few weeks later in the season than plants at lower elevations nearer the river. After fruits began to appear in mid- to late April and early May, herbivory was much less noticeable. Many plants that had been clipped generated new floral shoots after herbivory and continued to flower and set seed. By mid-May, seeds on plants at lower elevations had begun to dry and begin dropping.

Table 2. Phenology Observations Lomatium tuberosum on the Yakima Training Center in 1992

Date (1992)

February 22

February 29 - March 15

March 22 - April 15

April 21 - May 1

May 7 - May 15
Observed Stage of Plant

Plants at lower elevation $(<300 \mathrm{~m}$ ) emergent with floral stems elongating. Some individuals in flower, some in bud.

Most plants in full flower. Some plants showing evidence of herbivory and attempting to send up floral shoot.

Plants at lower elevations in fruit-plants at upper elevations beginning to form fruits. Fow plants at upper elevations still in flower.

Plants at all elevations completing seed set.

Plants at lower elevations dropping mature fruit. All plants observed in seed. 


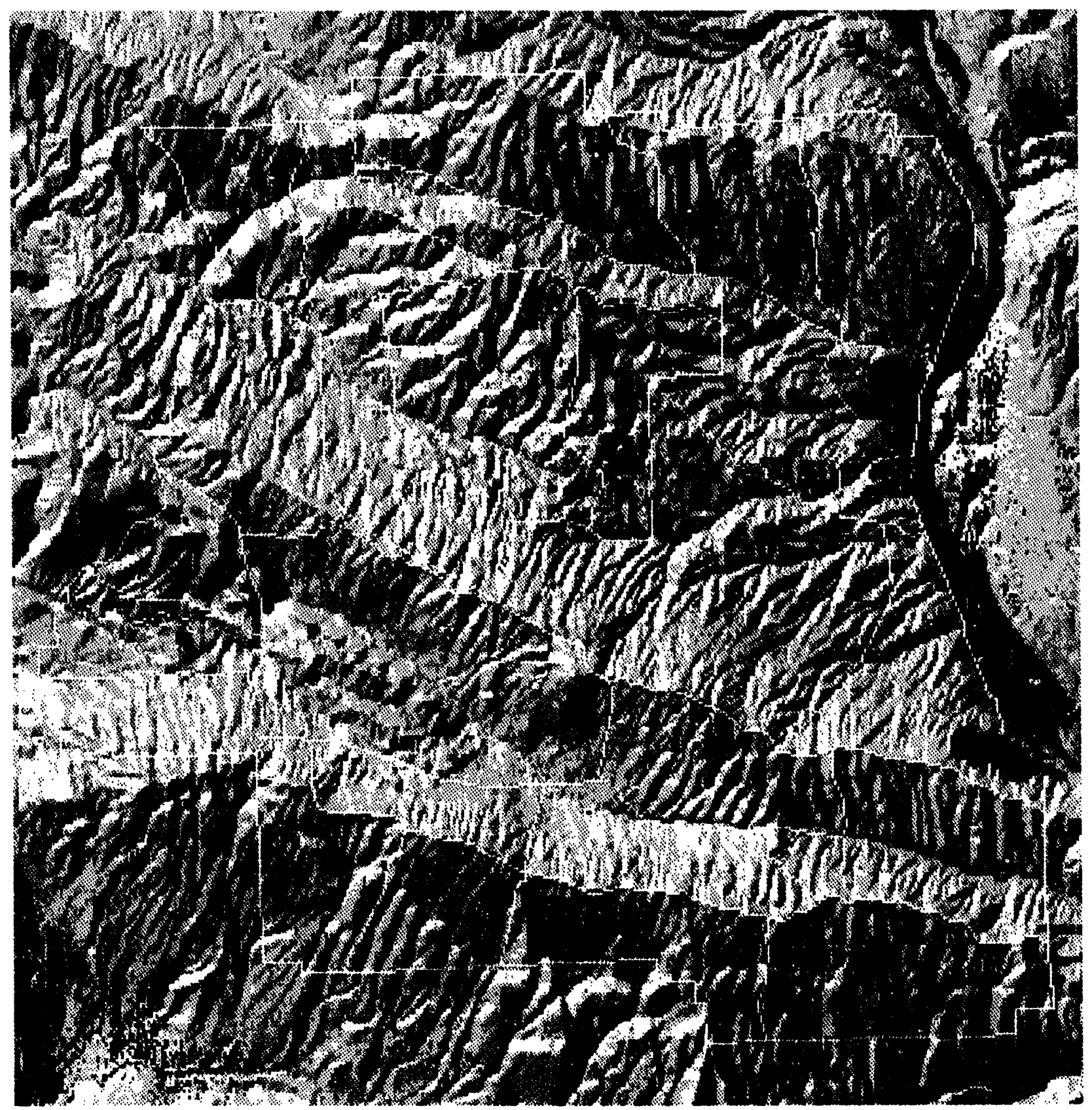

Lomatium Found on 610 ha

No Lomatium Found on 307 ha

Figure 3. Areas on the Yakima Training Center Surveyed on Foot and Habitat Areas Where Lomatium tuberosum was Found 
Populations of $L$. tuberosum and other Lomatium species were infected with an orange, rust-like fungus causing stem and fruit deformities. Mastrogiuseppe and Gill (1983) reported that populations of $L$. tuberosum in the Priest Rapids area located at that time were small, and most plants were vegetative. During our survey, thousands of plants were counted, and seedlings were found during February and March. The abundance of individuals seen during the 1992 spring growing season may have been a result of the early warm temperatures during the spring months in conjunction with spring rains that occurred during February, March, and April. The mild spring weather may have provided better than normal growing conditions for the desert parsley and resulted in increased population levels compared with previous surveys. Many of the areas where large numbers of plants were found consisted of slopes of more than $45^{\circ}$ that ware extremely unstable.

This plant species is not likely to be seriously impacted by cattle grazing on the YTC because its habitat is relatively inaccessible and undesirable for large animals. Grazing by sheep could impact Hoover's desert parsley because sheep are more likely to access steep slopes than cattle. Large-scale field maneuvers involving troop movement by foot across these steep slopes could also impact the species if such training were to occur between February and June. 


\section{References}

Constance, L., T. I. Chuang, and C. R. Bell. 1976. "Chromosome Numbers in Umbelliferae. V." Amer. J. Bot. 63(5):608-625.

Mastrogiuseppe, J. D., and S. J. Gill. 1983. "Steppe by Step: Understanding Priest Rapids Plants." Douglasia Occasional Papers. Vol. 1.

Mastrogiuseppe, J. D., S. J. Gill, K. S. Simmons, and G. K. Brown. 1985. "Morphologic and Cytotaxonomic Evaluation of Lomatium tuberosum (Apiaceae)." Brittonia 37(3):252-260.

Washington Natural Heritage Program. 1990. Endangered, Threatened and Sensitive Vascular Plants of Washington. Washington State Department of Natural Resources, Olympia, Washington. 


\section{Distribution}

No. of

Copies

\section{OFFSITE}

12 DOE/Office of Scientific and Technical Information

30 Commander Yakima Training Center

Attn: AFZH-Y-ENV

(Steven M. Kruger)

Yakima, WA 98901

5 R. W. Hanna

Department of the Army

HQ-I Corps

Attn: AFZH-DEQ

Fort Lewis, WA 98433-5000

V. W. Meadow

Department of Botany

Metropolitan State College

Denver, CO 80209
No. of

Copies

ONSITE

DOE Richland Operations Office

R. D. Hildebrand

20 Pacific Northwest Laboratory

L. L. Cadwell (10)

J. L. Downs

R. Mazaika

L. E. Rogers

Publication Coordinaton

Technical Report Files (5)

Routing

R. M. Ecker

M. J. Graham

P. M. Irving

C. S. Sloane

P. C. Hays/G. P. O'Connor (last)

Distr.1 


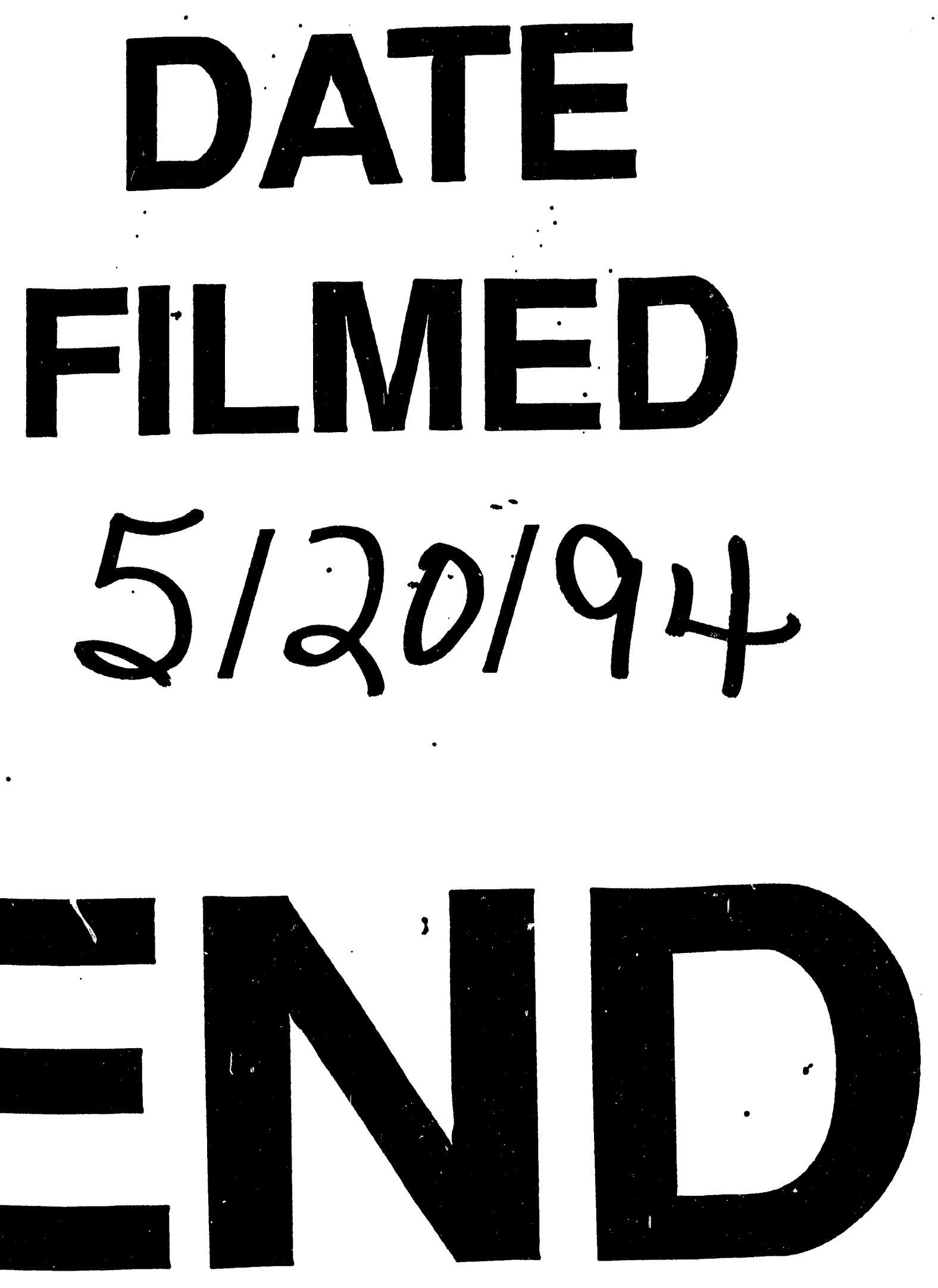


